\title{
Current Development Issues of Accounting Support of Innovation Venture Financing
}

\author{
Serhii F. Lehenchuk, Nataliia V. Valinkevych, Iryna M. Vyhivska, Hanna Yu. Khomenko
}

\begin{abstract}
The development of the concept of information support of venture capital management of enterprises in the conditions of formation of post-industrial society is quite new and relevant for the modern world and especially for Ukraine, as well as the intensification of innovation processes. The necessity of developing accounting, in particular reporting and analytical, tools for venture financing of innovations is theoretically substantiated and proved. Scientific search of directions for improving the accounting tools of venture innovations financing will promote the effective functioning of business entities that carry out venture activities, as well as avoidance threats and minimization the negative effects of economic risks, increasing the efficiency of the capital market in the part of venture investing, and in general, will accelerate the transition to an innovative model of economic development in Ukraine.
\end{abstract}

Keywords : Innovation, Venture Capital, Accounting Tools, Information Support

\section{INTRODUCTION}

The economic issues caused by the formation of the post-industrial economy and the inappropriateness of the system of accounting for and analytical support of the management of venture activity of innovative enterprises in the new economic conditions, necessitate the use of an innovative way of development of the economy of the country, as well as the formation and development of innovative infrastructure and attraction of venture capital investments.

In Ukraine, less than $2 \%$ of the total number of enterprises finance innovation through venture investments, which, in turn, significantly slows down the pace of innovation development in the country. The Ukrainian Venture Capital and Private Equity Association (UVCA), which has become a member of the European Private Equity \& Venture Capital Association (EVCA), aims to raise $\$ 40$ billion in investments in Ukraine by 2020. One of the reasons that holds back the lack of venture financing is the absence of information support of the management system, which would allow to ensure reliable and adequate reflection of venture activity of enterprises, facilitating decision-making by the subjects of their management and subjects of making venture

Lehenchuk Serhii F., Department of Accounting and Auditing, Zhytomyr Polytechnic State University, Zhytomyr, Ukraine. (Email: legenchyk2014@gmail.com)

Valinkevych Nataliia V. Department of Management and Entrepreneurship. Zhytomyr Polytechnic State University, Zhytomyr, Ukraine. (Email: natali1573@ukr.net)

Vygivska Iryna M., Department of Accounting and Auditing, Zhytomyr Polytechnic State University, Zhytomyr, Ukraine. (Email: virina1407@gmail.com) Zhytomyr Polytechnic State University, Zhytomyr, Ukraine. (Email: jakovets.anna@gmail.com).
Revised Version Manuscript Received on October 15, 2019.

Khomenko Hanna Yu. Department of Accounting and Auditing,

investments.

The current economic conditions require solving the issues of efficiency of functioning of domestic enterprises performing venture activities and corresponding main provisions of the Strategy of development of high-tech industries for Ukraine until 2025, medium-term priority directions of innovation activity of the national level for 2017-2021 and the Law of Ukraine "On the Priority Directions of Innovation Activity in Ukraine". In this context, the issue of developing the concept of information support for the venture capital management of innovative enterprises in the conditions of formation of a post-industrial society on the basis of taking into account the characteristics of the external entrepreneurial environment, the development of the venture industry and the activity of start-up companies in the country; methods of accounting and economic analysis of innovative enterprises activity, subjects of the venture industry and start-up companies is a question of acute need.

\section{METHODS}

In the course of solving certain research tasks, general scientific and special research methods were applied, which are the basis for developing accounting and analytical support for managing venture activities of innovative enterprises in the conditions of risk and economic transformations in Ukraine and the world by improving the capital market infrastructure in terms of the venture industry, minimizing information management risks of venture activities, improving the system of tax calculations of subjects of the venture industry and etc.

The research methods and expected results in developing the concept of information support for managing venture activities of enterprises in the context of the formation of a post-industrial society were:

1. Method of theoretical generalization, the dialectical method, method of a system approach and marketing research, which helped to determine the theoretical provisions of the implementation of venture activities by business entities and the identification of income and expenses of such activities in order to develop appropriate accounting models. This will become the basis for obtaining new economic knowledge about the economic transformations and information needs of venture capital entities in ensuring the ability of the state to protect national economic interests from external and internal threats at different levels of the public hierarchy. 
2. Formalization methods, surveys, and analysis of the needs of venture capital industry entities are an identifier of the needs of venture capital industry entities (venture capital firms, start-up companies, asset management companies, venture capital funds, business angels) in the information and qualitative characteristics of such information, which will be used to develop accounting and analytical support of the venture management system of enterprises.

\section{RESULTS AND DISCUSSION}

Studies of accounting for and analytical support of venture capital management over the past few decades have become a central issue in the scientific works of many foreign and domestic scientists, which is caused by the gradual formation of an innovative model of economic development and the emergence of a venture industry. In the works of scientists, the basic theoretical and methodological principles of the functioning of the venture capital industry, the particularities of the implementation of venture capital activities and the directions of development of accounting for and analytical support of its implementation have been developed. In particular, in the monograph of N.N. Kraus and E.N. Shevchenko "Innovation and venture capital in the systemic modernization of the national economy" (2013) [4] current issues in the development of innovative infrastructure of the economy are considered, the essence of the concept and the role of venture capital in the system of innovation activities are examined, the features of state regulation of venture financing in the world and Ukraine, its impact on innovation processes are highlighted. In the monograph of V.V. Zyanko, I.Yu. Epifanova and V.V. Zyanko "Innovative activity of enterprises and its financial support in the context of transformational changes in the economy of Ukraine" (2015) [10] the essence of the innovative process of enterprises as well as procedure for its financing are investigated, the features of venture capital investments, as the most promising area of activation of innovative activity in Ukraine are analyzed. In the work of F.J. Fabozzi "Entrepreneurial Finance and Accounting for High-Tech Companies" (2016) [3] the issue of venture risk, the business model of high-tech enterprises engaged in venture activity, the problematic aspects of its financing and the features of accounting and economic analysis are investigated.

The theoretical component of the research conducted by scientists published in scientific papers $[1 ; 2 ; 5 ; 6 ; 7 ; 8 ; 9]$, it is presented: firstly, by substantiating the concept of organizing a modern venture capital industry, specifying the peculiarities, mechanisms, and identifying specific objects of accounting and analysis of venture activity; secondly, the theoretical and organizational provisions of accounting for the costs of venture capital activities of venture capital enterprises indicating the degree of risk and the need for venture capital; thirdly, the directions of reforming the legislation of Ukraine regarding the implementation of venture activities of the enterprise; fourthly, accounting for and analytical support of managing venture financing of innovative enterprises in conditions of risk and economic transformation.

Despite this, insufficient attention has been paid by scientists to the issue of transforming the system of accounting and analytical support of managing venture activity of innovative enterprises in the conditions of modern economic transformations. This issue is quite new and relevant for the modern world and especially for Ukraine, the solution of which is necessary for the intensification of innovative processes and the transition to an innovative model of economic development.

The innovative type of economic development requires intensification of processes in the search for alternative non-traditional sources of business financing to support and develop innovative activities of domestic innovative enterprises. Venture financing today is a fairly popular and promising source of financing the activities of innovative enterprises focused on the development and production of high technology products. In modern economic conditions, venture capital finances about $2 / 3$ of all inventions and innovations around the world and is the main source of investment for the accelerated development of innovative activity in the world. Based on the results of a marketing desk study, the peculiarities of the activities of start-up companies in the EU countries were analyzed based on the study of reports from research agencies (KPMG, Ernst \& Young), which made it possible to determine the need for development of reporting and analytical tools (a package of management reporting, new calculation methods, a system of analytical indicators) to ensure the management of such enterprises.

In modern conditions, the priority strategic direction and an indispensable condition for full entry into the world economic system is the formation of an innovative model for the development of the Ukrainian economy. The transition to such a model implies the need for increased attention to the issue of the functioning of enterprises whose activities are associated with the development and promotion of innovative products characterized by a high level of risk.

Declaring the ideology of rapid innovation shifts in high-tech sectors of the economy is impossible without structural modernization of the accounting and analytical support system of enterprises venture activities management, since the latter has significant differences from traditional activities carried out by enterprises, in particular, it is characterized by the likelihood of complete bankruptcy and super-profits. At the same time, on the one hand, an important aspect is the substantiation of suggestions for the development of a system for searching, processing and presenting information about venture activities of enterprises, and on the other hand, the formation of suggestions for its processing and interpretation for entities that are willing to make venture investments in start-up companies and innovative projects.

Scientifically substantiated development of the theoretical foundations and organizational and economic principles of system of accounting and analytical support of the venture capital management system of enterprises will contribute to the effective functioning of venture capital enterprises, minimization of the negative consequences of economic risks, increasing the efficiency of the capital market in terms of venture investment, and in general will accelerate the
Published By:

\& Sciences Publication
Eyes Intelligence Engineering 
transition to an innovative model of economic development of the country. Therefore, it is necessary to identify and achieve the solution of the following tasks:

- to identify and analyze the needs of internal (subjects of management) and external (existing and potential venture investors) users of accounting information on venture activities of enterprises;

- to identify and classify risks associated with venture activities of enterprises, formulate ways to minimize them;

- to develop a system of accounting reserves to minimize the risks of venture capital enterprises;

- to develop a business model of a venture company, which will serve as the basis for building a system of accounting and analytical support for its management;

- to develop risk-oriented models for processing and presenting information on venture activities of enterprises (financial, managerial, tax, engineering), which will act as a means of generating operational, tactical and strategic information for managerial decisions making;

- to develop a system of internal and external accounting reporting on the status and results of venture activities of enterprises, taking into account the requests of domestic and foreign investors, as well as institutional investors;

- to form information support and a methodology for the formation of strategic scorecards for risk-oriented management of venture activities of enterprises based on the use of a balanced scorecard;

- to develop a regulation (standard) of accounting for expenses of start-up companies, which will allow providing information about them from the moment of their creation and throughout the entire period of their functioning;

- to develop a methodology of economic analysis of venture activities of enterprises at different stages of their life cycle, taking into account improvements in the existing accounting and analytical system of the enterprise;

- to suggest an assessment procedure and risk management algorithm for venture capital enterprises to minimize their negative economic consequences.

\section{CONCLUSION}

In the course of research on the development of information support of venture capital management of enterprises, practical and methodological developments may include the following: recommendations to the Project of Law of Ukraine "On venture activity for innovation sphere" regarding the clarification of terms such as "venture financing", "venture investment", "venture enterprise", which will contribute to the harmonization of terminology in the context of European integration; project of regulation (standard) of accounting for expenses of start-up companies; project of methodological recommendations on management accounting and analysis of the activities of startup companies; reporting package and project of methodological recommendations on accounting support for venture financing of innovative enterprises; the methodology of economic analysis of venture activities of enterprises at different stages of their life cycle; methodology of optimizing the risks of venture activity for business entities by developing an algorithm to minimize the negative economic consequences of the risks of their activities and creating a system of accounting reserves.
The vast majority of currently existing studies regarding the phenomenon of venture capital business are focused on the macroeconomic and financial aspects of the venture industry, in particular, issues of venture financing, venture investment are considered, and the features of the functioning and transformation of the activities of venture industry entities (venture enterprises, start-up companies, business angels, asset management companies, domestic and foreign venture investors) are examined. At the same time, almost no attention is paid to information support of the activities of venture enterprises and start-up companies. Since they are ordinary enterprises that carry out innovative developments and market innovative products, and on the other hand, to ensure their effective activity, it is necessary to develop a new transformed accounting and analytical support system that takes into account the specific features of venture capital enterprises (high level of risk, intensive attraction and use of intellectual capital, the possibility of obtaining super-profits / high probability of bankruptcy, the use of specific assets, etc.).

Thus, the solution of the issues of information support development of the process of creating innovative infrastructure and attracting venture investments in the innovative activities of business entities by domestic and foreign investors is extremely important for any state, which has the goal of steady and sustainable development, ensuring its national security, and complying with international advanced concepts of economic development of the country.

\section{REFERENCES}

1. Cumming, D. (2012). The Oxford Handbook of Venture Capital. Oxford University Press, $1056 \mathrm{p}$.

2. Derikolenko, A.N. (2016), Venchurnaia deiatelnost promushlennыkh predpryiatyi: teoryia, metodolohyia, praktyka [Venture activity of enterprises: theory, methodology, practice]. Sumy, Mechta, 303 p. [in Russian].

3. Fabozzi, F.J. (2016). Entrepreneurial Finance and Accounting for High-Tech Companies. MIT Press, $448 \mathrm{p}$.

4. Kraus, N.N. \& Shevchenko, E.N. (2013). Ynnovatsyonnaia deiatelnost predpryiatyi y ee fynansovoe obespechenye $\mathrm{v}$ uslovyiakh transformatsyonnukh yzmenenyi ekonomyky Ukraynu [Innovation activity and venture capital in system modernization of national economics]. Poltava, "Dyvosvit", 183 p. [in Russian].

5. Malerba, F. (2004). Sectoral system of Innovation. Concepts, Issues and Analyses of Six Major Sectors in Europe. Cambridge University Press, 519 p.

6. Petruk, A.M. \& Moshenskyy, S.Z. (2008). Teoryia ta praktyka venchurnoho fynansuvannyia [Theory and practice of venture financing]. Zhytomyr, ZSTU, $248 \mathrm{p}$. [in Ukrainian].

7. Ramsinghani, M. (2014). The Business of Venture Capital: Insights from Leading Practitioners on the Art of Raising a Fund, Deal Structuring, Value Creation, and Exit Strategy. John Wiley \& Sons, $432 \mathrm{p}$.

8. Smith, G.C. (2017). Start-Up \& Emerging Companies: Planning, Financing \& Operating the Successful Business. Law Journal Press, 1500 p. 
9. Venture Capital: International Comparions / Ed. by Milford B. Green. (2012). Routledge, 292 p.

10. Zyanko, V.V. \& Epifanova, I.Yu. \& Zyanko, V.V. (2015), Ynnovatsyonnaia deiatelnost predpryiatyi y ee fynansovoe obespechenye $\mathrm{v}$ uslovyiakh transformatsyonnukh yzmenenyi ekonomyky Ukraynu [Innovation activity of enterprises and its financial provision in conditions of transformation changes of Ukrainian economics]. Vinnitsa, VNTU, 172 p. [in Russian].

\section{AUTHORS PROFILE}

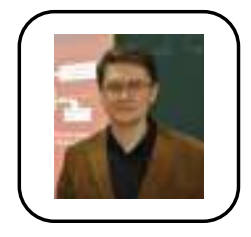

Serhii F. Lehenchuk is the Head of the Department of Accounting and Auditing, Zhytomyr Polytechnic State University. He is an accountant by profession with BSc from Zhytomyr State Technological University (ZSTU) and $\mathrm{PhD}$ in accounting, analysis and auditing from National agrarian University (Kyiv). He received his doctor of economics degree from ZSTU in 2011. His research interests are in general and positive accounting theory, accounting history, intangibles assets accounting, accounting reflection and economic analysis of venture activity.

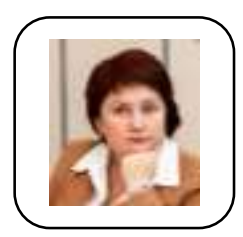

Nataliia V. Valinkevych - is the professor of the Department of Management and Entrepreneurship, Zhytomyr Polytechnic State University. By profession - engineer-economist, she received a bachelor's degree from the Institute of Entrepreneurship and Modern Technologies (Zhytomyr) and a PhD in industry economics (Council for the Study of Productive Forces of Ukraine, NAS of Ukraine, 2002, Kyiv). In 2015, she received her degree od Doctor of Economic Sciences in Economics and Enterprise Management (National University of Food Technologies, Kyiv). She is the head and responsible contractor of research and development. Head of scientific works of students of the 1 st and 2nd round at the All-Ukrainian competitions of student scientific works in economics, production management and entrepreneurship, where significant results are achieved by students. She has experience of international cooperation as a coordinator and participant of the project of Zhytomyr State Technological University in the development and implementation of the program in the field of economics and management of enterprises, implemented by the French agro-industrial association "KI-France" with the support of the Embassy of France in Ukraine. Her research interests are in economics and management of the enterprises, entrepreneurship, trading and stock exchanges activity.

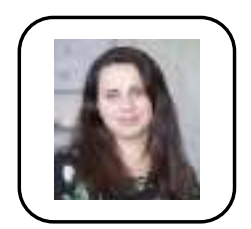

Iryna M. Vygivska is the Assistant Professor of the Department of Accounting and Auditing, Zhytomyr Polytechnic State University, Ukraine. She is an accountant by profession with BSc (2005) and $\mathrm{PhD}$ in accounting, analysis and auditing (2010) from Zhytomyr State Technological University. Her research interests are problems of accounting of economic activity in risks conditions, accounting and analytical support of risk management.

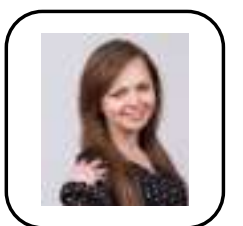

Hanna Yu. Khomenko. In 2012 graduated from the Zhytomyr State Technological University, Ukraine, specialty "Accounting and Auditing". In 2014 received Certificate of Proficiency in Polish as a Foreign Language (level B2). In 2015 defended thesis for obtaining the scientific degree of Candidate of Economic Sciences by specialty "accounting, analysis and auditing (by types of economic activity)". In 2016 received a qualification in specialty "Language and Literature (Polish)". Currently work as an Assistant Professor of the Department of Accounting and Auditing, Zhytomyr Polytechnic State University, Ukraine. Scientific interests: problems of accounting, analysis and taxation of transactions with venture financing of innovative enterprises, especially the use of the mechanism of venture philanthropy in financing charitable activities. Research efforts have resulted into more than 45 scientific papers, two books. 